\title{
Phytotherapeutic Potentials of Synedvilla Nodiflora: In-Vitro Quantification of Phytochemical Constituents, Antioxidant Capacities and Skin Enzymes Inhibiting Activities
}

\author{
Olugbenga Kayode Popoola ${ }^{1 *}$, Sunday Dele Oyeyemi ${ }^{2}$, Kayode Damilola Adekeye ${ }^{1}$, Abimbola \\ Micheal Akinyemi ${ }^{1}$, Kehinde Joshua Oyewole ${ }^{1}$, Ibukun Olawale Aremu ${ }^{1}$, Adeola Taoreed Ajao ${ }^{3}$ \\ and Taiwo Toluwabori Ajayi ${ }^{1}$ \\ ${ }^{1}$ Department of Chemistry, Ekiti State University, Nigeria
}

${ }^{2}$ Department of Plant Science and Biotechnology, Ekiti State University, Nigeria

${ }^{3}$ Department of Industrial Chemistry, Faculty of Science, Ekiti State University, Ado-Ekiti, Ekiti State, Nigeria

*Corresponding author: Olugbenga K Popoola, Department of Chemistry, Faculty of Science, Ekiti State University, Ado-Ekiti, Nigeria.

To Cite This Article: Olugbenga Kayode Popoola, Sunday Dele Oyeyemi, Kayode Damilola Adekeye, Abimbola Micheal Akinyemi, Phytotherapeutic Potentials of Synedvilla Nodiflora: In-Vitro Quantification of Phytochemical Constituents, Antioxidant Capacities and Skin Enzymes Inhibiting Activities. 2020 - 10(6). AJBSR.MS.ID.001571. DOI: 10.34297/AJBSR.2020.10.001571.

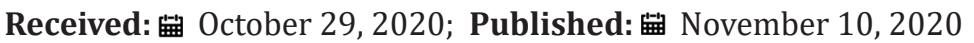

\begin{abstract}
Synedrella nodiflora is a useful medicinal plant that has been evaluated for its application in treatment of several ailments in sub-Saharan Africa and Bangladesh since time immemorial. In the present study, the methanol extract of the plant was investigated in-vitro for the presence of some essential phytochemicals, its antioxidant capacities, activity inhibition of skin degenerating enzymes of elastase and tyrosinase as well as its anti-lipid peroxidation activity. Determination of the total antioxidant capacities of the extract was achieved through evaluation of oxygen radical absorbance capacity (ORAC), ferric ion reducing antioxidant potential (FRAP) and iron-II induced inhibition of lipid peroxidation (LPO) assays. The quantitative analysis outcome of this study showed the relative abundance and concentration of flavanol, alkaloid, flavonol, phenolics, tannin, proanthocyanidins and saponin in Synedrella nodiflora methanol extract with the relative abundance (\%) of the phytochemicals is in the order of polyphenols (19.09)>Saponin (18.61)>flavonol (18.00)> proanthocyanidins (14.52) > flavanol (10.35)>Alkaloid (10.07)>tannins (9.36). The outcome of this study showed the ability of the plant extracts to scavenge free radicals and to inhibit degradation of lipids due to oxidative damage. Thus, $S$. nodiflora may be used in the treatment and management of oxidative stress and its related diseases. It was also observed that the plant extract possess a mild in-vitro tyrosinase and elastase inhibiting activities which implies that the plant may find applications in cosmetic preparations for skin depigmentation and anti-wrinkle agents in pharmaceutical formulations.
\end{abstract}

Keywords: Tyrosinase, Elastase, Synedrella Nodiflora, Phytochemicals; Phytotherapy, Antioxidant Phytochemicals, Phytotherapy, Antioxidant

\section{Introduction}

Many plants in nature have been assessed for their medicinal values. The background knowledge of the chemical constituents of a plant is highly desirable not only for the discovery of therapeutic agents but also because such information may be of value in disclosing new sources of economic materials like tannins, polyphenols, gum, oils, and other precursors for the synthesis of complex chemical substances [1]. Phytochemical screening enables tracing of the medicinal value of plants constituent and some biochemi cal substances that generate a definite physiological action on the human body [2,3]. Some important of the bioactive compounds in plants are the alkaloids, flavanol, flavonoids, tannins, alkaloids saponins, glycosides, cardenolides, proanthocyanidins and polyphenolic compounds [4-7].

Medicinal plants have found applications in treatments of several ailments and disorders like rheumatism, muscle swelling, inflammation, pains, diabetes, high blood pressure, oxidative stress, 
cancer etc. Such plants include Citrulus colocynthis, Acacia arabica, Ocimum gratissimum, Azadirachta indica, Phyllanthus amarus, Eclipta alba and Vernonia amygdalina [8-13]. The ethnopharmaceutical and ethnomedicinal applications of these plants are due to their varying degree of bioactive phytochemical constituents as well as their characteristic antioxidant properties [14-17]. The enzymes inhibiting properties of medicinal plants have been found exciting, adding more value to phytotherapy and making plants an excellent alternative to conventional synthetic chemicals in biomedicine. The alpha amylase and alpha glucosidase inhibition activities of some plants have been reported $[18,19]$. Recent independent researches by $[20,21,22]$ have shown the inhibitory effects of some plant materials on the enzyme tyrosinase present in the skin and they confirmed the possible application of such plant material in solving skin hyperpigmentation and premature skin aging problems.

Synedrella nodiflora is from the kingdom Plantae, infrakingdom of Streptophyta, subkingdom of Viridiplantae, division of Tracheophyta, superdivision of Embryophyta, subdivision of Spermatophytina, class of Magnoliopsida, order of Asterales, superorder of Asteranae, family of Asteraceae, genus of Synedrella Gaertn., and species of Synedrella nodiflora [23]. Synedrella nodiflora is a branched ephemeral herb that can grow up to $80 \mathrm{~cm}$ tall. It is characterized with a shallow root system which is usually strongly branched. The lower part of the stem may root at the nodes, especially in moist conditions while the leaves exist in opposite pairs and are usually 4-9 $\mathrm{cm}$ long. The presence of various bioactive constituents in the leaf extract of Synedrella nodiflora was reported after screening studies by $[24,25]$. Solvent extracts of Synedrella nodiflora have been shown to possess flavonoids, alkaloids, glycosides, steroids, tannins, saponins and phytosterols, triterpenoids gums and reducing sugars [2629]. The plant is essential for the treatment of various diseases and its leaves are eaten as a vegetable by some livestock and human. It also possesses sex hormone activity [30]. The leaves can be used as Pregnant Mare Serum Gonadotrophin supplier in animal husbandry and to improve reproductive parameters in female animals [31]. Literatures on the skin enzymes inhibitory activities of the plant are still limited according to SciFinder and Dictionary of natural products. This research is therefore directed at investigating the inhibitory actions of Synedrella nodiflora on the degenerating actions of enzymes present in the surface of the skin (tyrosinase and elastase) as well as its phytochemical constituents and antioxidant properties to support and validate its acclaimed ethnopharma-cological application.

\section{Materials and Methods}

\section{Chemicals and Reagent}

The reagents and standards used for this work were all of analytical grades with high percentage purity, secured from Sigma-Al- drich, Inc. (St. Louis, MO, USA) and Pascal scientific Ltd (Akure, Nigeria).

\section{Methods}

\section{Samples Collection and Preparation}

Aerial part of $S$. nodiflora was sourced from a local farm in Ikere-Ekiti $\left(7.4991^{\circ} \mathrm{N}, 5.2319^{\circ} \mathrm{E}\right)$, Ekiti State Nigeria. The plant was identified by the Herbarium curator at the Department of Biological Science Koladaisi University, Ibadan, Nigeria, where a voucher specimen number Kdu/IB/034 was assigned to the S. nodiflora. The obtained plant materials were prepared by washing them with distilled water and drying at room temperature for two weeks. The plant parts were crushed separately using pestle and mortar. Thereafter, the crushed parts were mixed together, pulverized by an electric blender into a homogenized powder, weighed and stored in different airtight sterile sample bottles pending analysis.

\section{Extraction}

The powdered plant material was extracted with methanol. Approximately $50 \mathrm{~g}$ of the powdered material was soaked in $1000 \mathrm{~mL}$ of the solvent in a vial for 72 hours for cold extraction. The extract was filtered and concentrated at $50{ }^{\circ} \mathrm{C}$ using rotary evaporator. The concentrate was stored in an air tight sample vial pending analysis.

\section{Quantitative Phytochemical Analysis}

\section{Determination of Total Phenol}

The total phenolic content of the aerial part of the plant was determined using the Folin-Ciocalteu method [32]. The procedure involved adding both distilled water and Folin-Ciocalteu reagent to a $125 \mu \mathrm{L}$ of the solvent extract. The mixture was allowed to stand for $6 \mathrm{~min}$ before the adding sodium carbonate solution $(7.0 \% \mathrm{w} / \mathrm{v})$. Thereafter, the mixture was allowed to stand for $90 \mathrm{~min}$ after which the absorbance was read at $760 \mathrm{~nm}$ on a SpectrumLab70 spectrophotometer and the result were expressed in terms of Gallic acid in $\mathrm{mg} / \mathrm{mL}$ of extract.

\section{Determination of Saponin}

The saponin concentration of the plant was determined using spectrophotometric method as described by [33]. In this method, $2.0 \mathrm{~g}$ of the extract was weighed into a beaker containing isobutyl alcohol (butan-2-ol) was added. The mixture was stirred and filtered through No 1 Whatman filter paper into a beaker containing $40 \%$ magnesium carbonate solution. Thereafter, $1 \mathrm{~mL}$ of the solution was transferred into a $500 \mathrm{~mL}$ volumetric flask. $2 \mathrm{~mL}$ iron (III) chloride $(\mathrm{FeCl} 3)$ solution was added to the solution and made up to mark with distilled water. The resulting solution was allowed to stand for $40 \mathrm{~min}$ for color development and absorbance was read at $380 \mathrm{~nm}$ on a SpectrumLab70 spectrophotometer. 


\section{Determination of Tannin}

The total tannin content was assessed by the experimental protocol of [18] with slight modifications. The tannin determination was carried out as follows. Approximately $0.5 \mathrm{~g}$ of the extract was diluted with $90 \%$ ethanol. $0.1 \mathrm{~mL}$ of the diluted sample was measured and added to $2 \mathrm{~mL}$ of Folin Ciocalteu reagent. After 10 min, $7.5 \mathrm{~mL}$ of sodium carbonate $(7 \%)$ solution was added and the mixture incubated for 2 hours. The absorbance of this mixture was measured at $760 \mathrm{~nm}$ and the tannin content was estimated using tannic acid (TA) curve as the standard.

\section{Determination of Alkaloid}

Alkaloid content of the plant's solvent extract was determined by weighing 5.0 g portion of the solvent extract into a beaker and $250 \mathrm{~mL}$ of $10 \%$ acetic acid in ethanol was added and allowed to stand for $5 \mathrm{~min}$. The mixture was filtered and the extract was concentrated on a water bath to one fifth of the original volume. Ammonium hydroxide solution was then added in drops to the concentrated extract until the precipitation was completed [19]. The precipitate was collected, washed severally with dilute ammonium hydroxide and filtered. The residue was dried in a desiccator and weighed.

\section{Flavanol Content}

The flavanol content of the S. nodiflora was determined spectrophotometrically in accordance to the modified method of Popoola et al. [7]. A $25 \mathrm{~mL} \mathrm{0.05 \%} 4$ dimethylaminocinnam-aldehyde (DMACA) solution prepared by dissolving DMACA in $8 \% \mathrm{HCl}$ prepared in methanol was added to $50 \mathrm{mg}$ of the solvent extract. The mixture was allowed to stand for $30 \mathrm{~min}$ and the absorbance was read on a SpectrumLab70 spectrophotometer at $640 \mathrm{~nm}$. The result was expressed in terms of catechin equivalents in $\mathrm{mg} \mathrm{CE} / \mathrm{mg}$ of extract. The determination was carried out in triplicate.

\section{Determination of Flavonol}

The flavonol content of the plant extract was determined by the method described (2008) with slight modifications. $2 \mathrm{~mL}$ of $\mathrm{AlCl} 3$ prepared in ethanol and $3 \mathrm{~mL}$ of $50 \mathrm{~g} / \mathrm{L}$ sodium acetate solution were added to $2 \mathrm{~mL}$ of the extracted sample in a test tube and mixed. The mixture was incubated for three hours ( $3 \mathrm{hrs}$ ) at $20 \mathrm{oC}$. Series of stock solution of $20,40,60,80$, and $100 \mu \mathrm{g} / \mathrm{mL}$ were thereafter prepared. The absorbance of the solutions was measured at $440 \mathrm{~nm}$ against a blank at $593 \mathrm{~nm}$ using a SpectrumLab70 spectrophotometer. The total flavonol content was calculated in terms of quercetin equivalent in $\mathrm{mg} \mathrm{QE} / \mathrm{mL}$ of sample from the calibration curve.

\section{Determination of Proanthocyanidins}

The total proanthocyanidins content of the plant material was determined by the procedure of [45]. An amount $0.5 \mathrm{~g}$ of the meth- anol extract of the plant material was vortex mixed with $3 \mathrm{~mL}$ of vanillin (4\%) prepared in methanol and $1.5 \mathrm{~mL}$ of hydrochloric acid. The mixture was allowed to stand for $15 \mathrm{~min}$ at ambient temperature. Thereafter, the absorbance was read at $500 \mathrm{~nm}$. The total proanthocyanidin content was expressed in terms of catechin (CE $\mathrm{mg} / \mathrm{g}$ ).

\section{Antioxidant Activities Determination}

\section{Ferric Reducing Antioxidants Potential (FRAP) Assay}

The FRAP assay was performed according to a modified method of [19]. $1 \mathrm{~mL}$ of the extracted sample $(1.0 \mathrm{mg} / \mathrm{mL})$ was mixed with $5 \mathrm{~mL}$ FRAP reagent in a test tube and vortex mixed. Blank samples were prepared for the methanol extract. The sample and blank were both incubated in water bath for 30 minutes at $37^{\circ} \mathrm{C}$. The absorbance of the samples was measured against the blank at $593 \mathrm{~nm}$. Series of stock solution with concentration of 20,40,60, 80 , and $100 \mu \mathrm{g} / \mathrm{mL}$ were prepared and using aqueous solution of $\mathrm{FeSO}_{4} \cdot 7 \mathrm{H}_{2} \mathrm{O}$ as standard curve.

\section{Inhibition Lipid Peroxidation Assay (LPO)}

For the determination of the lipid peroxidation inhibition assay, a little modification was made on the adopted method of Snijman [34]. In this method, both the plant extract and positive standards were prepare by incubating a mixture of $50 \mu \mathrm{L}$ anti-oxidative solutions (in different test tubes) corresponding to the extract or the positive standard and $300 \mu \mathrm{l}$ microsomes at $37^{\circ} \mathrm{C}$ for $30 \mathrm{~min}$ in a shaking water bath. $100 \mu \mathrm{l}$ of $\mathrm{FeSO}_{4}$ solution and $\mathrm{KCl}$-buffer were added to each resulting mixture. Each of the mixtures was incubated at $37^{\circ} \mathrm{C}$ for 1 hour in a shaking water bath. After the incubation, $1 \mathrm{~mL}$ trichloroacetic acid (TCA) reagent was added to each test tube containing each mixture, vortex mixed and centrifuged at $2000 \mathrm{rpm}$ for $15 \mathrm{~min}$. Thereafter, each supernatant was decanted; $1 \mathrm{~mL}$ of each supernatant was removed and added to new test tubes containing approximately $1 \mathrm{~mL} 0.67 \%$ TBA solution. The samples were further vortex mixed and heated for $20 \mathrm{~min}$ at $90{ }^{\circ} \mathrm{C}$ in a water-bath. Absorbance of each sample and standard was measured at $532 \mathrm{~nm}$. The percentage inhibition was measured according to Equation (I).

$$
\% \text { inhibition }=\frac{\text { Astandard }- \text { Asample }}{\text { Astandard }} \times 100 \ldots \ldots \ldots \ldots \ldots \ldots \ldots . . .(\mathrm{I})
$$

\section{Oxygen radical absorbance capacity (ORAC) assay}

The methods of $[22,35]$ were adopted for the ORAC assay: The reaction was carried out in a $75 \mathrm{mM}$ phosphate buffer ( $\mathrm{pH}$ 7.4) medium that yielded a final reaction mixture of $200 \mu \mathrm{L}$. The Plant extract $(10 \mu \mathrm{L}$, varying from 1 to $50 \mu \mathrm{g} / \mathrm{mL})$ and fluorescein $(100 \mu \mathrm{L}$; $1.6 \mu \mathrm{g} / \mathrm{mL}$ ) solutions were added to the reaction mixture and vortex. The resulting mixture was pre incubated for $5 \mathrm{~min}$ at $37^{\circ} \mathrm{C}$. Fifty micro liters $(50 \mu \mathrm{L})$ of peroxide radical AAPH solution was added immediately and decaying of fluorescence was scanned for $35 \mathrm{~min}$ (at $1 \mathrm{~min}$ interval) at $37^{\circ} \mathrm{C}$ [35]. The decay in fluorescence was 
measured with a fluorescence detector at $486 \mathrm{~nm}$ excitation and $538 \mathrm{~nm}$ emission wavelengths. The ORAC value was calculated by dividing the sample curve-area by the trolox curve area [22]. The ORAC value of the extract was expressed as $\mathrm{mg} / \mathrm{mL}$ Trolox equivalent (TE) of dry extract.

\section{Enzymes Inhibition Activities}

\section{Tyrosinase Inhibition Assay}

The aerial part of the $S$. nodiflora was also assayed for its tyrosinase inhibition activity in a 96-well reader using a modified procedure of [36]. The anti tyrosinase activity of the plant was carried out at room temperature. A reaction mixture of $30 \mu \mathrm{L}$ potassium phosphate buffer (50 Mm, pH 6.8) and 343 Units/mL mushroom tyrosinase and $110 \mu \mathrm{L}$ L-tyrosine $2 \mathrm{mM}$ was pre-incubated for 15 mins before adding $L$-tyrosine. The resulting mixture upon addition of L-tyrosine was further incubated for 15 mins before measuring the absorbance at $490 \mathrm{~nm}$. A mixture without L-tyrosine was used as blank while the reaction mixture with the corresponding solvents (without plant material) was used as standard; kojic acid was served as the positive standard. The percentage inhibition of tyrosinase was calculated using Equation (II) while the IC50 value obtained for extract was from the dose-effect curves.

$$
\text { Tyrosinase inhibition }(\%)=\frac{(\mathrm{A}-\mathrm{B})-(\mathrm{C}-\mathrm{D})}{(\mathrm{A}-\mathrm{B})} \times 100 \text {. }
$$

Where $\mathrm{A}=$ Absorbance of standard with enzyme; $\mathrm{B}=\mathrm{Absor}-$ bance of the standard without enzyme; $\mathrm{C}=$ Absorbance of sample with enzyme; $\mathrm{D}=$ Absorbance of sample without enzyme.

\section{Elastase Inhibition Assay}

The Elastase inhibition activity of the plant material was assayed by modifying the method of [37]. In this method, N-succ-(Ala)3-nitroanilide (SANA) was used as the substrate the release of p-nitronilide was monitored. The assay was performed in $0.2 \mathrm{M}$ Tris- $\mathrm{HCl}$ buffer ( $\mathrm{pH}$ 8.0). Porcine pancreatic elastase (PPE) was dissolved to make a 100 Units/mL stock solution in sterile water. The prepared substrate SANA was dissolved in the tris- $\mathrm{HCl}$ buffer without the plant extract. The plant extract $(10 \mu \mathrm{L})$ of varying concentrations $(20-100 \mu \mathrm{g} / \mathrm{mL})$ was pre-incubated with $10 \mu \mathrm{L}$ enzyme (0.01 Units/ $\mathrm{mL}$ ) and $125 \mu \mathrm{L}$ of Tris-HCL for $10 \mathrm{~min}$; thereafter, the substrate was added while the reaction proceeded further for $10 \mathrm{~min}$ at $25^{\circ} \mathrm{C}$. The absorbance was measured at $410 \mathrm{~nm}$ wavelength immediately after incubation. The percentage inhibitions were calculated using Equation (III). IC50 values were obtained for from the dose-effect curves.

Elastase inhibition $(\%)=\frac{(\mathrm{A}-\mathrm{B})}{\mathrm{A}} 100$........

Where $\mathrm{A}$ is the absorbance at $410 \mathrm{~nm}$ without plant extract and $B$ is the absorbance at $410 \mathrm{~nm}$ with plant extract.

\section{Statistical Analysis}

Values shown in tables are the means and the standard deviations of three parallel measurements. The IC50 values of the enzymes (elastase and tyrosinase) inhibition activities of the plant's extract were obtained from linear regression curve of enzymes inhibitory activities (\%) versus extract's concentrations $(\mu \mathrm{g} / \mathrm{mL})$ using Microsoft Excel (2010).

\section{Results and Discussion}

The phytochemical analyses of the $S$. nodiflora extract revealed the relative abundance (Figure 1) and concentration (Figure 2) of individual component present as saponin, alkaloids, polyphenols, proanthocyanidins, flavanol, tannin and flavonol (Figure 1). The phytochemical constituents of medicinal plants have been reported to be directly associated with their biological activities [10, 25, 38]. Saponins, alkaloids, glycoside, polyphenols, proan-thocyanidins, flavanol, tannin and flavonol content are some of the phytochemicals known to be directly associated with antioxidant activities. These compounds are often referred to as powerful chain-breaking antioxidants [39-41]. The presence of these bioactive phytochemicals in the plant showed that the plant is a useful antioxidant material that may exert protective effects against inflammation, cancer diabetes and cardiovascular disease; they may also play a vital role in microbial inhibition.

\section{Relative abundance (\%) of the phytochemicals}

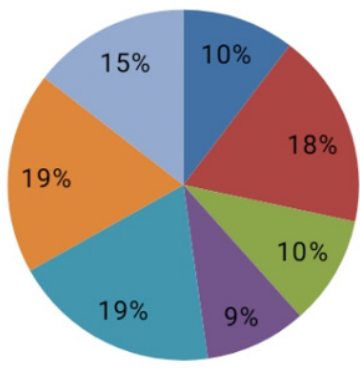

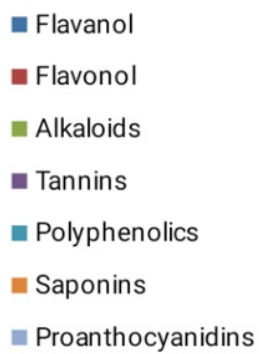

Figure 1: Relative abundance of the evaluated phytochemical constituents of S. nodiflora. 


\section{Phytochemical Constituents}

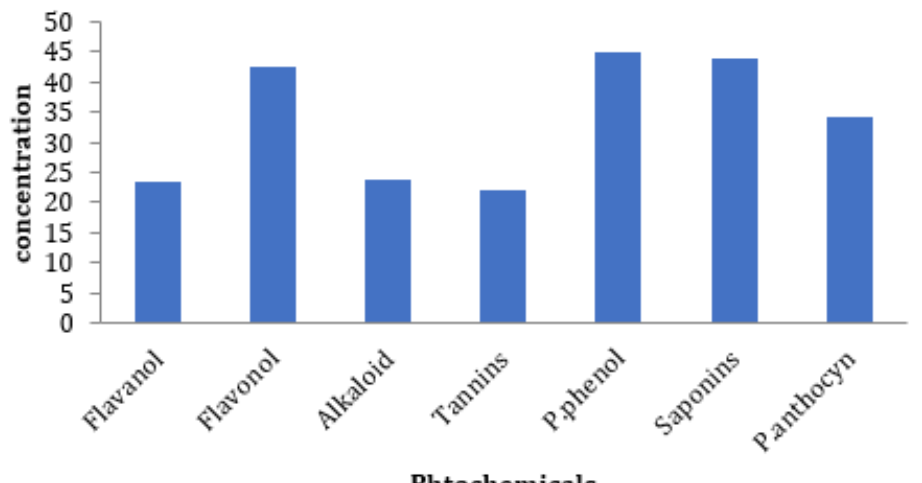

Phtochemicals

Figure 2: Concentration of the evaluated phytochemical constituents of S. nodiflora.

\section{Anti Tyrosinase activitiy}

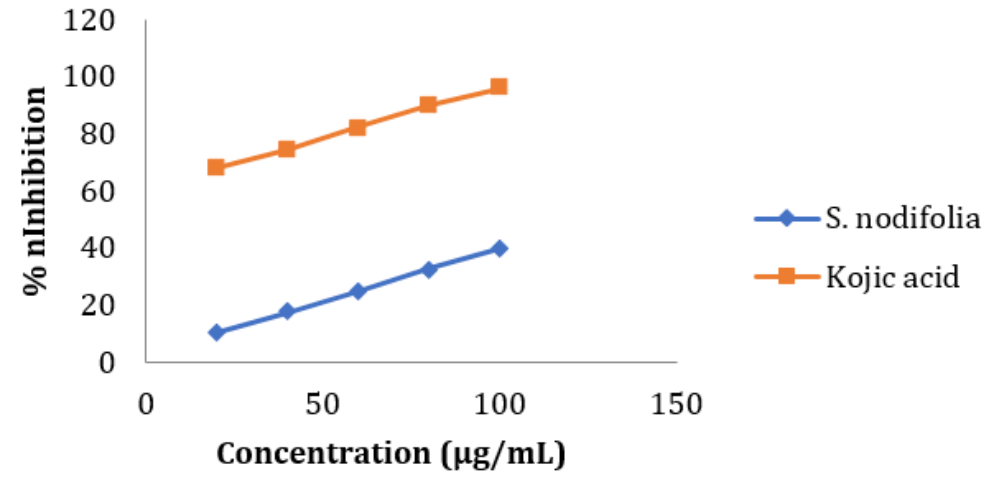

Figure 3:

Further, the results of the present study demonstrate that the plant exhibit variations in its phytochemical constituents (Table 1). Polyhenols (44.97 $\pm 1.33 \mathrm{mg}$ of GAE/mL) was the most abundant $(19.09 \%)$ of the plant's evaluated phytochemicals while tannin $(22.00 \pm 0.16 \mathrm{mg} / \mathrm{g})$ was estimated to be the least abundant $(9.36$ $\%)$. The relative abundance (\%) of the phytochemicals is in the order of polyphenols (19.09) > Saponin (18.61) > flavonol $(18.00)>$ proanthocyanidins (14.52) > flavanol (10.35) > Alkaloid (10.07) > tannins (9.36) (Table 1). The mechanism of lipid peroxidation has been suggested to proceed via a free radical chain reaction Zhiyong and Yuanzong [42] which has been associated with cell damage in biomembranes $[22,43]$. The damage has been shown to initiate the development cancerous cells, cardiovascular diseases and diabetes according to $[44,45]$. The potency of the $S$. nodiflora extract to inhibit the process of lipid peroxidation was investigated in this study. The methanol extract of the plant was able inhibit lipid peroxidation by $55.60 \%$ well below that of the standard EGCG (90.95\%). However, the value (Table 2 ) recorded for this plant showed its mild ability to inhibit lipid peroxidation processes (Table 2). The reducing power of a compound is related to its electron transfer ability and may therefore serve as a significant indicator of its potential antioxidant activity [7]. To estimate the reductive ability of the plant's extract, the ferric ion reducing antioxidant potential of the extract was assayed. The result of this study showed $\mathrm{Fe}^{3+}$ to $\mathrm{Fe}^{2+}$ transformation potential of the plant's extract with FRAP value of $681.10 \pm 0.13 \mathrm{mg} /$ $\mathrm{mL}$ which is higher than that of the standard $3.20 \pm 0.01 \mathrm{mg} / \mathrm{mL}$ as shown in Table 2 . The higher reducing ability of the plant's extract implies a higher electron donating ability of the extract.

Table 1: Concentrations and the relative abundance of the evaluated phytochemicals in S. nodiflora.

\begin{tabular}{|c|c|c|}
\hline Phytochemicals & Concentrations \pm SD & Relative abundance (\%) \\
\hline Flavanol & $24.38 \pm 0.03 \mathrm{mg} \mathrm{CE} / \mathrm{g}$ & 10.35 \\
\hline Flavonol & $42.41 \pm 1.53 \mathrm{mg} \mathrm{QE} / \mathrm{mL}$ & 18 \\
\hline
\end{tabular}




\begin{tabular}{|c|c|c|}
\hline Alkaloids & $23.72 \pm 3.21 \mathrm{mg} / \mathrm{g}$ & 10.07 \\
\hline Tannins & $22.00 \pm 0.16 \mathrm{mg} \mathrm{TA} / \mathrm{g}$ & 19.36 \\
\hline Polyphenols & $44.97 \pm 1.33 \mathrm{mg} \mathrm{of} \mathrm{GAE} / \mathrm{mL}$ & 18.61 \\
\hline Saponins & $43.84 \pm 1.41 \mathrm{mg} / \mathrm{mL}$ & 14.52 \\
\hline Proanthocyanidins & $34.19 \pm 1.01 \mathrm{mg} \mathrm{CE} / \mathrm{g}$ & \\
\hline
\end{tabular}

Table 2: Antioxidant activities of the S.nodiflora.

\begin{tabular}{|c|c|c|c|}
\hline Antioxidants Assay & FRAP (mg/mL) & LPO inhibition (\%) & ORAC $\left(\mu \mathrm{M} \mathrm{TE} / \mathrm{g} \times 10^{3}\right)$ \\
\hline Extract & $6.81 \pm 0.13$ & 55.6 & 7.85 \\
\hline EGCG & $3.20 .50 \pm 0.01$ & 90.95 & 6.1 \\
\hline
\end{tabular}

Table 3: Enzyme inhibition activities of S.nodiflora.

\begin{tabular}{|c|c|c|}
\hline Enzymes inhibition Assay & 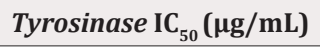 & 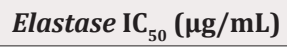 \\
\hline Extract & 112.9 & $71.20 \mu \mathrm{g} / \mathrm{mL}$ \\
\hline Kojic acid & 11.25 & - \\
\hline Xanthone & - & 20.2 \\
\hline
\end{tabular}

\section{The Oxygen Radical Absorbance Capacity (ORAC)}

The Oxygen Radical Absorbance Capacity of the plant's extract is presented in Table 2. The ORAC values were determined in terms of Trolox equivalents (TE). The $S$. nodiflora extract exhibited a higher capacity to absorb oxygen radicals than the standard. The value ORAC value recorded for the plant's extract is $7.85 \mu \mathrm{M} \mathrm{TE} / \mathrm{g} \times 103$ while that of EGCG is $6.10 \mu \mathrm{M} \mathrm{TE} / \mathrm{g} \times 103$. The higher oxygen radical absorbance capacity of the plant's extract may imply that there are more electron withdrawing groups in the extract than in the standard. The antioxidant capacities and lipid peroxidation inhibition activity of the plant is mainly due to the presence and abundance of the bioactive compounds like Tannins, alkaloids, polyphenols and flavonol in the extract. The presence of phenolic compounds has been shown to correlate to the antioxidant activity of natural plant products $[7,27,28]$ (Table 3$)$.

The inhibitory effect of $S$. nodiflora on tyrosinase activity was investigated in-vitro and the result is presented in Table 3. The assay was carried out to show the possibility of using the plant to solve problems relating skin pigmentation. The potential of the plant's extract and kojic acid (standard) to inhibit this enzyme increased from 20 to $100 \mu \mathrm{g} / \mathrm{mL}$ with respect to the results obtained from this study. This shows that the inhibition activity of the materials increased with increasing concentration of the extract (Figure 3,4). The $S$. nodifora extract and kojic acid showed optimum inhibition (39.75 and $95.9 \%$ respectively) at the concentration of $100 \mu \mathrm{g} /$ $\mathrm{mL}$ (Table 3). The IC50 value for the plant's extract was $112.90 \mu \mathrm{g} /$ $\mathrm{mL}$ while that of the standard was $9.25 \mu \mathrm{g} / \mathrm{mL}$. The enzyme tyrosinase was susceptible and mildly inhibited by the plant as a result of strong tyrosinase inhibitors like flavanol, flavonol and polyphenols present in the plant's extract. South African Rooibos (Aspalathus linearis), Aspilia africana (Compositae) and Melanthera scanden are plants evaluated to have contained these phytochemicals and shown to have inhibited the enzyme tyrosinase $[7,22]$.

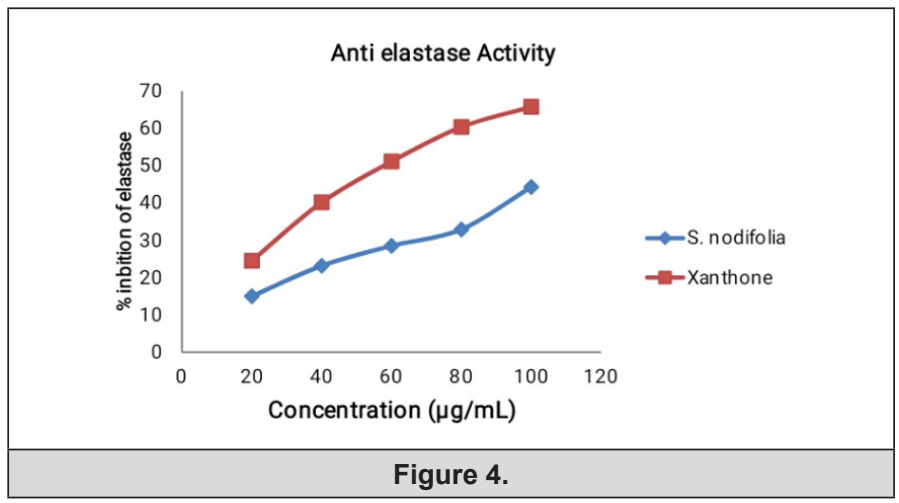

The tyrosinase inhibition activity of the plant showed its value as a promising material for solving the problems of hyperpigmentation or may be used for depigmentation purpose. Elastase inhibition activity of the $S$. nodiflora was also investigated to evaluate its applicability in skin treatment and problems solving involving skin wrinkling and dry skin. The performance efficiency of the plant's extract to inhibit Elastase at optimum concentration $(100 \mu \mathrm{g} / \mathrm{mL})$ was $44.4 \%$. The percentage by which both the extract and the standard (xanthone) inhibited the enzyme increase with their increasing concentrations respectively. It is possible that increasing the concentration of the extract beyond $100 \mu \mathrm{g} / \mathrm{mL}$ could increase its inhibition activities. However, the plant material was able to demonstrate ability to maintain healthy skin and anti-wrinkle activities even at lower concentrations.

\section{Conclusion}

The presence of free radicals and reactive oxygen species is a major cause of skin aging and cellular oxidative stress related problems. Medicinal plants have found applications in solving deleterious effects of free radicals and reactive oxygen species in biological 
system making them excellent natural alternatives to conventional synthetic chemicals. This study has shown the promising phytotherapeutic value of Synedvilla nodiflora. The plant has demonstrated good free radical scavenging ability, reactive oxygen absorbing capacity and anti-lipid peroxidation ability and hence, a good antioxidant. In addition $S$. nodiflora possess the ability to inhibit the enzymes tyrosinase and elastase making it an economic important plant for skin treatment and healthy skin maintenance. To meet skin-whitening and anti-wrinkle's properties demand for cosmetic preparation in the global market, $S$. nodiflora as well as some other plant's extract capable of inhibiting tyrosinase and elastase activities may be good choice. The outcome of this study confirms the acclaimed ethnopharmacological applications of $S$. nodiflora and its biological roles in solving oxidative stress related diseases.

\section{References}

1. Erinle OD (2012) Phytochemical Screening of Scent leaf (Ocimum gratissimum) and bitter leaf (Vernonia amygdalina) extracts. ND Project Pp1-5.

2. Allero AA, Afolayan AJ (2006) Antimicrobial Activity of Solanum tuberosum. African Journal of Biotechnology 5: 269-272.

3. Koche D, Shirsat R, Syed I, Bhadange DG (2010) Phytochemical screening of eight ethnomedicinal plants from Akola District (MS). International Journal of Pharma and Bioscience 1(4): 256- 259.

4. Gusev N, Nemereshina O, Petrova G, Sychev M (2012) Evaluation of biologically active substances and antibacterial activity of herbal drugs from Veronica L. Rusian Journal of Biopharmaceuticals 4(6): 17-22.

5. Grundemann C, Garcia-Kaufer M, Sauer B, Stangenberg E, Konczol M, et al. (2013) Traditionally used Veronica officinalis inhibits proinflammatory mediators via the NF-kB signalling pathway in a human lung cell line. J Ethnopharmacol 145(1): 118-126.

6. Živković J, Barreira JC, Stojković D, Ćebović T, SantosBuelg C, et al. (2014) Phenolic profile, antibacterial, antimutagenic and antitumour evaluation of Veronica urticifolia Jacq. Journal of Functional Foods 9: 192-201.

7. Popoola OK, Faleye FJ, Adekeye DK, Ajayi TT, Azimi AA, et al. (2020) Comparative Impact of Seasonal variation on the Antityrosinase activity, Antioxidant capacities and Phytochemical constituents of Aspilia africana (Compositae) and Melanthera scanden. Biomed J Sci \& Tech Res 31(3): 24173-24178.

8. Khosla P, Bhanwra S, Singh J, Seth S, Srivastava R, et al. (2000) A study of hypoglycaemic effects of Azadirachta indica (Neem) in normal and alloxan diabetic rabbits. Indian J Physiol Pharmacol 44(1): 69-74.

9. Mithun N, Shashidhara S, Vivek KR, Eclipta A (2011) A review on its phytochemical and pharmacological profile. Journal of Pharmacologyonline 1: 345-357.

10. Shetti A, Sanakal R, Kaliwal B (2012) Antidiabetic effect of ethanolic leaf extract of Phyllanthus amarus in alloxan induced diabetic mice. Asian J Plant Sci Res 2(1): 11-5.

11. Ahangarpour A, Oroojan A (2013) Effect of crust and seed hydroalcoholic and aqueous extracts and pulp hydroalcoholic extract of Citrullus colocynthis on glucose, insulin and FIRI level in insulin resistant male rat's. Horizon Med Sci 19(3): 149-154.

12. Hegazy GA, Alnoury AM, Gad HG (2013) The role of Acacia Arabica extract as an antidiabetic, antihyperlipidemic, and antioxidant in streptozotocin-induced diabetic rats. Saudi medical journal 34(7): 727733.
13. Oladosu-Ajayi RN, Dienye HE, Ajayi CT, Agha IU (2016) Vernonia amygdalina (Bitter leaf) extracts as preservative for catfish, Clarias gariepinus. IJNF 3(1): 102-108.

14. Namsa ND, Tag H, Mandal M, Kalita P, Das AK, et al. (2009) An Ethnobotanical Study of Traditional Anti-Inflammatory Plants Used by the Lohit Community of Arunachal Pradesh, India. J Ethnopharmacology 125(2): 234-245.

15. Du L, Shen Y, Zhang X, Prinyawiwatkul W, Xu Z, et al. (2014) Antioxidantrich phyto-chemicals in miracle berry (Synsepalum dulcificum) and antioxidant activity of its extracts. Food Chem 153: 279-284.

16. Fuentes L, Valdenegro M, Gómez MG, Ayala-Raso A, Quiroga E, et al. (2016) Characterization of fruit development and potential health benefits of arrayan (Luma apiculata), a native berry of South America. Food Chem 196: 1239-1247.

17. Wilkowska A, Ambroziak W, Czyzowska A, Adamiec J (2016) Effect of Microen-capsulation by Spray-Drying and Freeze-Drying Technique on the Antioxidant Properties of Blueberry (Vaccinium myrtillus) Juice Polyphenolic Compounds. Polish Journal of Food Nutrition Sciences 66: $11-16$.

18. Keerthana G, Kalaivani MK, Sumathy A (2013) In-vitro alpha amylase inhibitory and anti-oxidant activities of ethanolic extract of croton bonplandianum. Asian Journal of Pharmaceutical and Clinical Research 6(4): 32-36.

19. Akinwunmi OA, Adekeye DK, Olagboye SA (2020) Phytochemical quantification, in vitro antioxidant and antidiabetic potentials of methanol and dichloromethane extracts of Triclisia subcordata (Oliv) leaves. Trends Phytochem Res 4(1): 17-24

20. Hanh NTM, Phung NKP, Phuong QND (2017) Studying on Tyrosinase Inhibition Activity of Some Vietnamese Folk Plants Aims to Use in SkinWhitening Cosmetics. American Journal of Plant Sciences 8: 1319-1328.

21. Popoola OK (2019) Skin Depigmentation Profiles of Ethanolic Fraction of the South African "Green" Cyclopia intermedia and Other Related Biological Potentials. American Journal of Biological Chemistry 7(5): 65-71.

22. Popoola OK, Adedara TO, Ajao AT, Akinrinlola M, Olasanmi AO, et al. (2019) Effect of Fermentation on the Factor of Skin bPigmentation Inhibitory Activity and Total Antioxidant Capacities Demonstrated by the South African Rooibos (Aspalathus linearis). Biomed J Sci \& Tech Res 20(4): 15195-15202.

23. TICA. The International Compositae Alliance, Belguim.

24. Amoateng P, Koffuor GA, Sarpong K, Agyapong KO (2011) Free radical scavenging and anti-lipid peroxidative effects of a hydro-ethanolic extract of the whole plant of Synedrella nodiflora (L.) Gaertn (Asteraceae). Free Radicals and Antioxidants 1(3): 70-78.

25. Amoateng P, Woode E, Kombian SB (2012) Anticonvulsant and related neuropharmacological effects of the whole plant extract of Synedrella nodiflora (L.) Gaertn (Asteraceae). J Pharm Bioall Sci 4: 140-148.

26. Rathi MJ, Gopalkrishnan S (2005) Insecticidal activity of aerial parts of Synedrella nodiflora (L.) Gartn (Compositae) on Sapodeptera latura (FAB). Journal of central European Agriculture 6: 323-328.

27. Woode E, Amoateng P, Abotsi WM (2011) Ethopharmacological analysis of the effects of the whole plant extract of Synedrella nodiflora (L.) Gaertn (Asteraceae) in murine models. Der Pharmacia Sinica 2: 54-67.

28. Hossain S, Mallik J (2012) Phytochemical screening and in vitro evaluation of reducing power of ethanol extracts of Synedrella nodiflora. IJRRPAS 2(5): 879-890.

29. Hidayat S (2014) Synedrella nodiflora (L.) Gaertner [Internet] Record from Proseabase. Van Valkenburg, et al. (edn). PROSEA (Plant Resources of South-East Asia) Foundation, Indonesia. 
30. Mannan A, Ahmad K (1978) Preliminary study of sex hormones of medical importance in Bangladeshi plants. Bangladesh Med Res Counc Bull 4(2): 78-85.

31. Koutinhouin GB, Kpodekon TM, Tougan UP, Hanzen CH, Zonatchia GG, et al. (2015) Comparative survey of Synedrella nodiflora (L.) Gaertn leaves and commercial Pregnant Mare Serum Gonadotrophin (Gonaser®) on reproductive performance in rabbits does. Tropical Animal Health and Production.

32. Singleton VL, Rossi JA (1956) Colorimetry of total phenolics with phosphomolybdic-phosphotungstic acid reagents. Am J Enol Viticul 16(3): 144-158.

33. Brunner JH (1984) Direct spectrophotometer determination of saponin. Anal Chem 34 (396): 1314-1326.

34. Snijman PW, Joubert E, Ferreira D, Li X, Ding Y, et al. (2009) Antioxidant activity of the dihydrochalcones aspalathin and nothofagin and their corresponding flavones in relation to other rooibos (Aspalathus linearis) flavonoids, epigallocatechin gallate, and trolox. Journal of Agriculture and Food Chemistry 57: 6678-6684.

35. Liyanaarachchia GD, Samarasekeraa JKRR, Mahanamab KRRM, Hemalalc KDP (2018) Tyrosinase, elastase, hyaluronidase, inhibitory and antioxidant activity of Sri Lankan medicinal plants for novel cosmeceuticals. Industrial Crops \& Products 111: 597-605.

36. Chiari M, Joray MB, Ruiz G, Palacios SM, Carpinella MC (2010) Tyrosinase inhibitory activity of native plants from Central Argentina: isolation of an active principle from Lithraea molleoides. Food Chem 120 (1): 10-14.

37. Chompo J, Upadhyay A, Fukuta M, Tawata S (2012) Effect of Alpinia zerumbet components on antioxidant and skin disease-related enzymes. BMC Complementary and Alternative Medicine 12: 106-114.
38. Ohunayo A, Adekeye D, Dauda O, Odeniyi I, Popoola O, et al. (2020) Microbial Profile of the Phyllosphere and the Antimicrobial Potency of Ficus vogelii Extracts. Journal of Pharmaceutical Sciences and Research 12(1): 191-195.

39. Cakir A, Mavi A, Yıldırım A, Duru ME, Harmandar M, et al. (2003) Isolation and characterization of antioxidant phenolic compounds from the aerial parts of Hypericum hyssopifolium L by activity-guided fractionation. J Ethnopharmacol 87(1): 73-83.

40. Maisuthisakul P, Suttajit M, Pongsawatmanit R (2007) Assessment of phenolic content and free radical-scavenging capacity of some Thai indigenous plants. Food Chemiostry 100(4): 1409-1418.

41. Ksouri R, Megdiche W, Falleh H, Trabelsi N, Boulaaba M, et al. (2008) Influence of biological, environmental and technical factors on phenolic content and antioxidant activities of Tunisian halophytes. C R Biol 331(11): 865-873.

42.Zhiyong C, Yuanzong L (2004) Reducing power: the measure of antioxidant activities of reductant compounds?. Journal of Redox Report 9(4): 213-217.

43. Halliwell B (1989) Free Radicals. Biol Med 7: 645.

44. Badmus JA, Adedosu TO, Fatoki JO, Adegbite VA, Adaramoye OA, et al (2011) Lipid peroxidation inhibition and antiradical activities of some leaf fractions of Mangifera indica. Acta Pol Pharm 68(1): 23-29.

45. Ashafa OT, Grierson DS, Afolayan AJ (2010) In vitro Antioxidant Activity of Extracts From the leaves of Felicia Muricata Thunb. An Underutilized Medicinal Plant in Eastern Cape Province, South Africa. Afr J Tradit Complement Altern Med 7(4): 296-302. 